\title{
Rediscovering the Cooperative Enterprise: A Systematic Review of Current Topics and Avenues for Future Research
}

\author{
Andres Felipe Camargo Benavides ${ }^{1}$ (D) Michel Ehrenhard $^{1}$
}

Accepted: 31 January 2021/Published online: 8 March 2021

(C) The Author(s) 2021

\begin{abstract}
For decades, the cooperative enterprise (CE) produces market goods and/or provides services in the interest to its members, such as communities, customers, and suppliers. The upsurge of interest in social enterprises, and their balancing of social and economic interests, has also led to a renewed interest in CEs, often seen as a specific type of social enterprise. However, from an organizational perspective, this renewed interest has been both limited and scattered over a variety of fields. In this paper, we systematically review papers on $\mathrm{CE}$ in the mainstream organizational literature, defined as literature in the fields of economics, business, management and sociology. Our review integrates and synthesizes the current topics in the mainstream organizational literature and provides a number of avenues for future research. In addition, we compare our findings in the organizational literature to the social issues literature as these appeared to be quite complimentary. We found multilevel studies, determination of social impact—in particular measurable impact, managerial practices for sustainable (organisational) development, and the entrepreneurial opportunity generation process as the four key avenues for future research.
\end{abstract}

Andres Felipe Camargo Benavides

a.f.camargobenavides@utwente.nl

Michel Ehrenhard

m.l.ehrenhard@utwente.nl

1 Faculty of Behavioural, Management and Social Sciences, Hightech Business \& Entrepreneurship Department,

Entrepreneurship \& Technology Management Section, University of Twente, Drienerlolaan 5, 7522 NB, Enschede, Netherlands
Keywords Cooperative enterprise · Organizational structure · Organizational forms · Social enterprise $\cdot$ Hybrid organizations

\section{Introduction}

Negative side effects of business have become more and more visible over the past decade in terms of social, environmental and economic problems. For instance, the global financial crisis that started in the USA in 2007 as a result of subprime mortgage lending (Ackermann 2008) and more recently the Volkswagen scandal about clean air violations, fuelled the debate about the ethical behaviour of firms (EPA 2016). Such events have led to intensified societal calls demanding that companies look beyond pure profit maximization (Kotler and Lee 2005; Porter and Kramer 2011). Here, organizational scholars can contribute by defining new business models that compel improved connections among businesses, societies and communities (Porter and Kramer 2011). As a consequence, research interest in such alternative business models has increased in the past decade under a variety of labels, such as cooperative enterprise (Cheney et al. 2014), social enterprise (Doherty et al. 2014), hybrid organizations (Battilana and Lee 2014), and social entrepreneurship (Zahra et al. 2008). The common characteristic that these organizational forms seem to be better able to meet both social and economic goals.

In particular, the cooperative enterprise (CE) is recognized already for decades as an organizational form that can address socio-economic problems, respond to societal needs, overcome market failures and alleviate problems for customers, members and society (Cheney et al. 2014; Costa et al. 2012; Storey et al. 2014). Scholars recognize that the 
cooperative model contains elements of social entrepreneurship, social enterprises and hybrid organizations (Doherty et al. 2014). Likewise, the International Labour Organization recognizes the relevance of CEs "as important in improving the living and working conditions of women and men globally as well as making essential infrastructure and services available even in areas neglected by the state and investor-driven enterprises" (ILO 2017).

Unfortunately, the literature on the $\mathrm{CE}$ as an organizational form is highly fragmented in what is currently considered as mainstream organizational literatures, i.e. the fields of economics, management, business, and sociology. For example, Mazzarol et al. (2014a, p. 11) report that "scholars working with a wide range of backgrounds [...] including economics, agriculture, sociology, social policy, regional studies, management, marketing, entrepreneurship, labour studies, history, political economy, law, accounting and finance" are studying cooperatives. In an effort to synthesize current knowledge of $\mathrm{CE}$ in the mainstream organizational literature-broadly ranging from work in economics, management, and business, to sociology — we aim to contribute to the knowledge of organizational aspects of one of the four SE models identified (Defourny and Nyssens 2017) and empirically tested (Defourny et al. 2020): the social cooperative model. By studying the $\mathrm{CE}$ from an organizational perspective, we seek to complement literature dealing with CE's historical development, legal requirements or specific societal impact or policy, for example in the field of social issues. Thus, the research question for this study is as follows: 'What future avenues for research can be derived from the current topics of $\mathrm{CE}$ research in the organizational literature?'.

Our study makes various contributions to benefit both research and practice. First, our study explores a number of reasons why $\mathrm{CE}$ have received limited attention so far in the mainstream organizational literature. Second, our study synthesizes the literature on $\mathrm{CE}$ in the mainstream organizational literature. In this way, we connect a variety of insights that help in better understanding the $\mathrm{CE}$ as an organizational form. Additionally, this allows us to provide an overview of the various organizational mechanisms available to those responsible for CE effectiveness, especially with respect to sustainable development practices and entrepreneurial opportunity generation. Third, by comparing the mainstream organizational literature to the social issues' literature on $\mathrm{CE}$, a valuable bridge is built between those studying effective organizational design versus those primarily studying effective societal impact. Finally, we highlight the need for multilevel studies into CEs.

The structure of our paper is as follows. We first demarcate the $\mathrm{CE}$ and describe the mainstream organizational literature that we used as a basis for this study by providing an overview of definitions, the nature, and research contexts of CE. Next, we conduct a systematic literature review of the current body of knowledge on $\mathrm{CE}$ in organizational research. Based on our review, we categorize and cluster the main themes discussed in the organizational literature with regard to $\mathrm{CE}$. Finally, we derive future research avenues by integrating the available organizational knowledge with respect to the $\mathrm{CE}$ organizational form.

\section{Cooperative Enterprise: Definition, Nature and Context}

Defining the CE is not as straightforward as it seems, since various definitions appear in the literature (see Table 1). Each definition can be associated with a particular theoretical framework. The International Cooperative Alliance (ICA) defines a $\mathrm{CE}$ as follows: "A cooperative is an autonomous association of persons united voluntarily to meet their common economic, social and cultural needs and aspirations through a jointly owned and democratically controlled enterprise" (ICA 2020b). This is a definition widely accepted by practitioners and scholars alike (Battaglia et al. 2015; Bernardi and Miani 2014).

However, despite the widespread use of this definition, CE can also be owned by companies, not only by persons. For instance, suppliers can own an interfirm cooperative, as is common in agribusiness (Hendrikse and Feng 2013). Persons are therefore to be understood in this definition as consisting of both independent natural and legal entities. Monteiro and Stewart (2015) offer a definition from the ownership and rights control perspective, given the particular ownership structure of $\mathrm{CE}$, and they also provide a perspective on the role of the members in the decisionmaking process. Othman et al. (2014) explain briefly who the owner is, how control is exercised and how the benefits are received in a $\mathrm{CE}$. Table 1 summarizes these and more definitions associated with $\mathrm{CE}$.

Connecting the nature of the cooperative model to its identity, the ICA provides values and guidelines for characterising CE identity. "Cooperatives are based on the values of self-help, self-responsibility, democracy, equality, equity and solidarity. According to their founders' tradition, cooperative members believe in the ethical values of honesty, openness, social responsibility and caring for others" (ICA 2020a,2020b). There are seven ICA principles, namely (1) Voluntary and open membership; (2) Democratic member control; (3) Members' economic participation; (4) Autonomy and independence; (5) Education, training and information; (6) Co-operation among Cooperatives; and (7) Community concern. These 
Table 1 Definitions of cooperative

\begin{tabular}{|c|c|}
\hline Author(s) & Definition \\
\hline Monteiro and Stewart (2015) & $\begin{array}{l}\text { A cooperative can be defined as an enterprise in which the rights to residual control are assigned to one of the } \\
\text { other (i.e. other than capital suppliers) contracting parties, and in which these "members" exercise control } \\
\text { on the basis of "one member, one vote". Once again, decision-making might be delegated to specialist } \\
\text { managers (p. 93) }\end{array}$ \\
\hline Lan et al. (2014) & Cooperatives are collectively owned enterprises (p. 380) \\
\hline Othman et al. (2014) & $\begin{array}{l}\text { Cooperatives are user-owned, user-controlled enterprises that benefit their members on the basis of use (p. } \\
485 \text { ) }\end{array}$ \\
\hline Datta and Gailey (2012) & A collective form of entrepreneurship (p. 569) \\
\hline Soboh et al. (2009) & $\begin{array}{l}\text { A cooperative can be defined as a user-owned and user-controlled organization that aims to benefit its } \\
\text { members (p. 447) }\end{array}$ \\
\hline $\begin{array}{l}\text { Diaz-Foncea and Marcuello } \\
\text { (2013) }\end{array}$ & $\begin{array}{l}\text { Cooperatives can be defined as an organizational form in which (a) the users or beneficiaries of the goods or } \\
\text { services produced by the organization also have ultimate decision-making power; (b) the owners have an } \\
\text { unusual transaction relationship with the enterprise, as they are not only investors, but also employees, } \\
\text { suppliers and/or customers; and (c) organizational governance typically does not discriminate among } \\
\text { members in terms of rights; in essence there is typically a one person/one vote rule (p. 240) }\end{array}$ \\
\hline Hendrikse and Feng (2013) & $\begin{array}{l}\text { An interfirm cooperative (IFC) is defined as an enterprise collectively owned by many other firms staying in a } \\
\text { specified relation for a specific purpose (p. 501-502) }\end{array}$ \\
\hline $\begin{array}{l}\text { ICA (2020b)—retrieved from } \\
\text { ICA website }\end{array}$ & $\begin{array}{l}\text { An autonomous association of persons united voluntarily to meet their common economic, social and cultural } \\
\text { needs and aspirations through a jointly owned and democratically controlled enterprise }\end{array}$ \\
\hline
\end{tabular}

guidelines help to put the mission of $\mathrm{CE}$ into practice in their own context (Cheney et al. 2014; Novkovic 2008).

Historically, CE have played a key role in social and economic development (Stiglitz 2009, p. 350) in that, they have produced and marketed goods in the agricultural, and food industries (Battilani and Zamagni 2012), provided services in wholesale and retail industries (Balnave and Patmore 2012; Mason 2012; Robertson 2012; Webster 2012) to its members, their customers and communities (Balnave and Patmore 2010; Battaglia et al. 2015; Fernandez 2014). The $\mathrm{CE}$ can be seen as an ideal hybrid organization that is able to create both social and economic value. Further, as an organizational form the CE can take a variety of legal structures, from an agricultural cooperative to a financial institution or a credit provider (Mazzarol et al. 2014a).

\section{Research Approach}

We conducted a review to assess the current state of the literature on $\mathrm{CE}$, as this "helps develop a reliable knowledge base by accumulating knowledge from a range of studies" (Tranfield et al. 2003, p. 220). This review follows a systematic review approach, which means that we follow a systematic method of collecting and reviewing articles by following the steps explicated by Tranfield et al. (2003). Relevant papers selected for the study are examined for recurring key concepts, the nature of CEs, used theoretical approaches and the specific research context, which are clustered into a number of themes. Using this methodology enabled an appraisal of the current body of knowledge in management field and closely related literature on the topic, by which we identified potential gaps for future research in this domain.

The first challenge for this study was to define the primary search strings as the use of the keyword 'cooperative' and related variants led to thousands of documents unrelated to the $\mathrm{CE}$ but focussing on variants of the verb cooperating. In particular, we faced the challenge that 'cooperative' has various meanings within the mainstream organization literature-defined here as belonging to the economics, management, business and sociology fieldsreferring to concepts such as cooperation, cooperative strategy (Parmigiani and Rivera-Santos 2011), collaboration (Strand and Freeman 2015), alliances (Albers et al. 2016), relations between organizations and their partners (Barringer and Harrison 2000). However, none of these papers dealt with the $\mathrm{CE}$ as a specific entity but with organizations or people collaborating.

Consequently, the review protocol was based on the following selection criteria and procedures. The first step was to identify studies focused specifically on the CE. We searched the Web of Science database with the keywords "cooperative" and "co-operative". The primary search string we used was "cooperative*". The keyword included an asterisk (*) to find keyword variations such as "cooperative" and "co-operative". Next, we limited our results to the categories Economics, Management, Business, and Sociology. We chose these categories as the fields they 
represent are those most closely dealing with organizations and organizing specifically. We further limited our results studies published as journal articles, research notes and reviews. Furthermore, we selected only those studies published in or after 2000, as very few papers on CE were published before-and the most important older work would surface in our final review step. After these initial five selection steps in the Web of Science database, we selected papers based on the relevance of the title and then on the abstract's content to be sure that the dealt with CE. We excluded a few papers that were not written in English. Based on our full reading of the set of remaining relevant papers, we searched back-and-forwards for additional relevant documents listed in the papers' references. In this step, we added an additional number of often mentioned relevant journal articles, reviews, book chapters and books. After these steps, our full set of documents used in our review consisted of 101 sources. Our selection steps and the resulting size of our paper sample in each step is mentioned in Table 2.

We clustered the organizational research along a number of key themes, based on often recurring concepts and topics, theoretical approaches, the nature of the CE and specific research contexts. These themes were addressed by scholars in various ways, using both qualitative and quantitative methods to assess performance, survival, growth, and efficiency of CEs. Also, some of these studies involve direct comparison between CEs and investorowned firms (IOFs). We further noticed a relatively recent blossoming interest in CEs. Approximately, $60 \%$ of the papers in our review appeared in the past decade (cf., in the social issues' literature, the interest has increased substantially in the past five years). Furthermore, we also found studies undertaken on CE in Africa, South America, Asia and Oceania, evidencing how the research landscape on other continents differs from the traditional cooperative movement in Western, i.e. Anglo-American and European contexts. In Fig. 1, we have depicted how we framed and categorized our key themes to provide an integrated overview of the $\mathrm{CE}$ as a research field, showing the main themes and concepts we identified in relation to the CE.

\section{Findings}

In our findings, we discuss the five most prominent themes that emerged from our clustering and categorization. These themes are: (a) reasons for the limited attention in the organizational literature; (b) ownership and governance; (c) efficiency and performance; (d) strategy and growth; (e) social enterprise and hybrids, and (f) social entrepreneurship. In addition, we compare our findings in the organizational literature to the research on cooperatives in the social issues literature.

\section{Limited Attention for the $\mathrm{CE}$ in the Current Mainstream Organizational Literature}

During the review process, a range of possible reasons emerged for research on CE being treated as less relevant to organizational scholars in economics, business, management and sociology. Since scholars consider the $\mathrm{CE}$ as a

Table 2 Results per step of the systematic literature review

\begin{tabular}{|c|c|c|}
\hline Phase & Step and purpose & Result \\
\hline $\begin{array}{l}\text { Scope of the } \\
\text { study }\end{array}$ & Define research scope & Initial keywords and terms (concept) \\
\hline Search string & $\begin{array}{l}\text { Identify the relevant literature and generate a pool of } \\
\text { potential literature using the keywords }\end{array}$ & 1.688 potential documents \\
\hline $\begin{array}{l}\text { Select } \\
\text { category }\end{array}$ & Select Web of Science categories & $\begin{array}{l}608 \text { documents from the following categories: economics (319), } \\
\text { management (139), business (101) and sociology (107) }\end{array}$ \\
\hline $\begin{array}{l}\text { Select } \\
\text { document }\end{array}$ & Select document & 460 documents: articles (440), notes (11) and reviews (9) \\
\hline Select year & 2000 and later & 330 documents remaining \\
\hline Select by title & Relevance based on titles & 97 documents remaining \\
\hline $\begin{array}{l}\text { Select by } \\
\text { topic }\end{array}$ & Relevance based on abstract & 82 documents remaining \\
\hline $\begin{array}{l}\text { Select } \\
\text { language }\end{array}$ & Documents written in English & 78 documents available \\
\hline $\begin{array}{l}\text { Backward } \\
\text { and forward }\end{array}$ & Additional Documents & Added 15 articles, reviews (2), book chapters (5), books (2) \\
\hline Final set & Full set of documents to be read & 101 documents \\
\hline
\end{tabular}




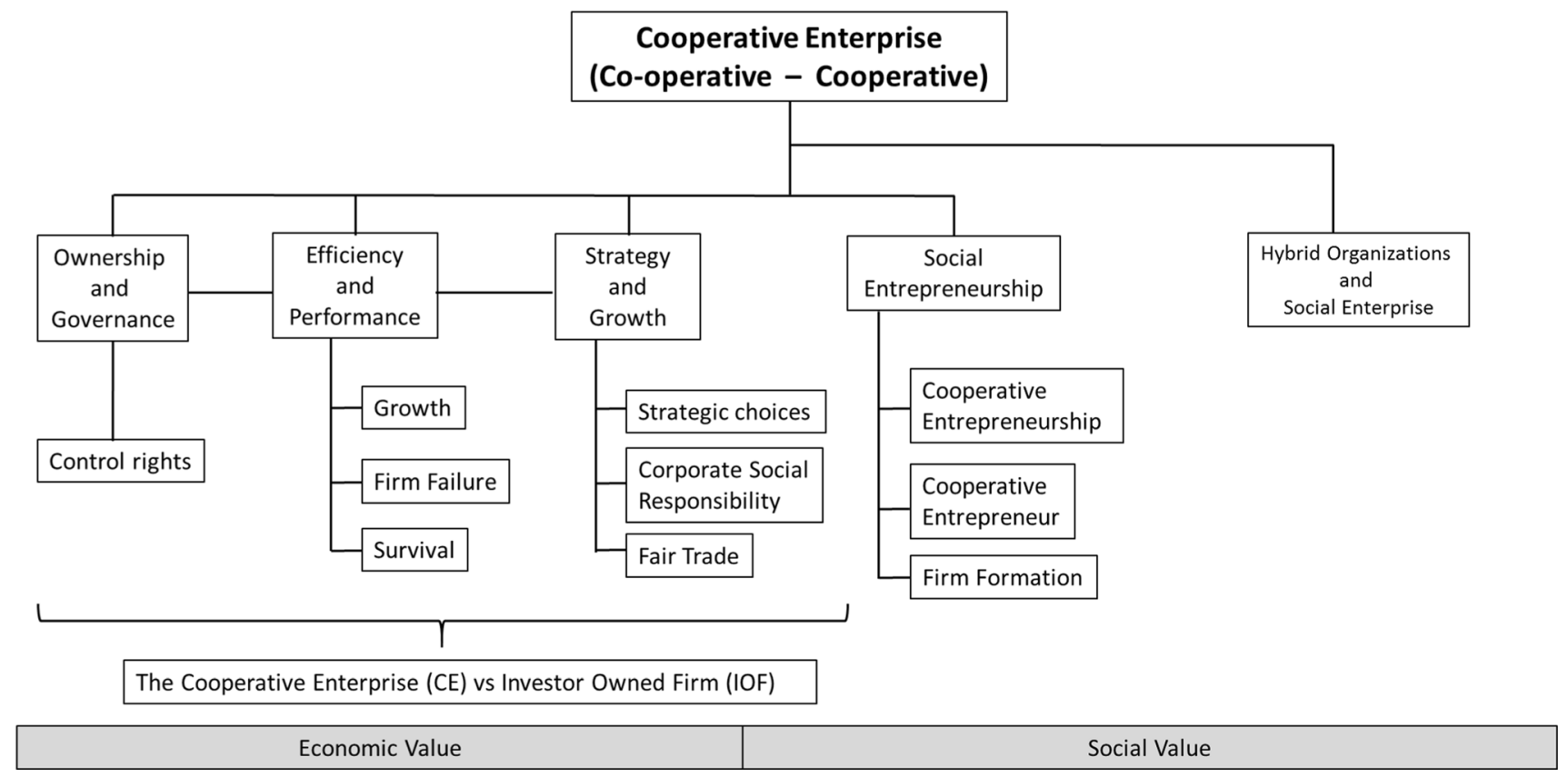

Fig. 1 Research landscape on cooperative enterprise

player in the economic market, it assumes that the $\mathrm{CE}$ conducts itself in the same way and with the same opportunistic logic as the IOF counterpart. Similarly, the predominant economic model of capitalism (Sandmo 2011) in which the for-profit corporation is the model for all other organizational forms, and which is positioned according to logics such as capital and profit maximization, and efficiency, creates the impression that the cooperative model and non-investor-owned sectors are of limited relevance (Mintzberg 1996). Additionally, the economic nature of the firm (Putterman and Kroszner 1996), as well as the economic neoliberalism framework, reinforce these capitalist logics which are characterized by strong private property rights, free markets, and free trade (Harvey 2005). Although CE do not pursue profit maximization as a central goal, the rational of cost efficiency still drives CE performance (Hendrikse and Veerman 2001).

This lack of interest in CE is reflected, for example, in this organizational form not being dealt with in economic textbooks (Hill 2000). For instance, between 1905 and 2005 Kalmi (2007) compiled a longitudinal sample of Economics textbooks at the University of Helsinki, Finland. $\mathrm{He}$ argued that a shift in the economics paradigm explains why CE have been omitted in Economics textbooks. Additionally, this lack of interest is also reflected in media reports. A study performed by (Mangan and Byrne 2018) analysed media coverage and reports in the United Kingdom regarding to the bank sector, where business reporting capitalist narratives, the study identified how media play a role delegitimizing co-operative banks.
$\mathrm{CE}$ are often considered to be economically less efficient than IOFs (Hendrikse and Feng 2013). In the past, Porter and Scully (1987) pointed out that cooperatives can suffer from structural inefficiencies: "The horizon problem, the transferability problem, and the control problem have implications for technical efficiency, factor-price efficiency and scale efficiency" (p. 498). Similarly, Hendrikse and Feng (2013) explain how CE face the horizon problem, control problem and portfolio problem. Basically, because of the limited transferability of ownership rights and to CE' special features, CE can suffer an underinvestment problem, because the members are disincentivized to provide resources for long term investment strategies. Besides, a diversification problem influencing the CE's decisionmaking process arises. These aspects are explained from the ownership rights perspective, because CE has a different ownership configuration. These problems appear to withhold CE from achieving efficiency. Despite the arguments mentioned above, Fahlbeck (2007) reports no support for a horizon problem in agricultural cooperatives or efficiency.

Another possible explanation for the limited research attention lies in the social focus of CE. Although CE typically are commercially and economically oriented, they are at the same time socially focused. Levi and Davis (2008) claim that this dual orientation of CE has a negative impact on their profits and efficiency. However, the interplay between social and economic objectives is inherent to CE. Unlike IOFs, CE have a broad social mission that transcends their economic role (Kalmi 2007). CE promote 
social stability and alleviate poverty in the communities where they are established (Simmons and Birchall 2008). In the following sections, we discuss papers that demonstrate that research on CE does not merit limited attention as inefficiencies, ownership and governance, and the social focus of CE are not as problematic as portrayed.

\section{Cooperative Enterprise Ownership and Governance}

Two key elements are central to $\mathrm{CE}$ and the cooperative model, namely ownership and governance structure. There is a deep link between the ownership structure and governance of a cooperative. The particular ownership structure requires a corresponding governance mechanism to manage CE. Hansmann (1996), who wrote extensively on ownership, governance structure and rights, claimed that non-capitalist firms which include $\mathrm{CE}$, play a vital role within many sectors in the economy (Hansmann 1999). Research shows that CE can be owned by consumers (Ashforth and Reingen 2014), workers (Lambru and Petrescu 2014; Leca et al. 2014; Storey et al. 2014; Vuotto 2012) and suppliers (Boone and Ozcan 2013). Thereby within member-based organization, democracy, equality, and power, play a role to equalize and balance ownership and governance structure (Jaumier 2017; Limnios et al. 2018). Thus, currently, many research avenues on $\mathrm{CE}$ ownership, governance structure remains open.

In this regard, Birchall (2010) proposed the concept of member-owned business (MOB) which brings together the multiple roles that members play in a $\mathrm{CE}$. He addresses the fact that a large spectrum of business organizations actually work with this ownership configuration. Additionally, in this regard Mazzarol et al. (2018) developed a conceptual framework of this concept to understand the nature's complexity of MOB. A cooperative firm is a user-owned and user-controlled enterprise (Soboh et al. 2009), which means the owners have a dual role (Nunez-Nickel and Moyano-Fuentes 2004). Additionally, this ownership structure of $\mathrm{CE}$ assures a higher probability of survival during the time into market (Monteiro and Stewart 2015; Nunez-Nickel and Moyano-Fuentes 2004).

From a governance perspective, scholars often present the $\mathrm{CE}$ as an alternative organization form and alternative business model (Cheney et al. 2014; Loconto and Simbua 2012; Paranque and Willmott 2014) that faces global challenges, reduces poverty and fosters social integration. Therefore, inter-governmental organizations generally support the cooperative movement, since CE create an environment that fosters economic and social development. For example, the International Labour Organization (ILO), in its 90th session on 3 June 2002, recognized the importance of the $\mathrm{CE}$ in economic and social development, and so promoted the CE (ILO 2002). Moreover, the United
Nations (UN) declared 2012 to be the International Year of Cooperatives.

In addition, based on the concepts of ownership, governance structure and voting rights, Chaddad and Cook (2004) present an analysis of ownership and rights. They developed a conceptual typology from an ownership rights perspective, using various cases of cooperatives that had faced survival challenges, and in response started to evolve towards a new cooperative model. There is evidence that to survive into the market, the traditional CE needs to be more flexible. Therefore, organizational innovations come up as adaptations to the new economic environment (Katz and Boland 2002), and even more so when the CE is subject to a political and governmental constraints (Lambru and Petrescu 2014) or cultural constraints that affect its daily running (Bernardi and Greenwood 2014; Bernardi and Miani 2014).

The CE has to be economically efficient to fulfil the needs of members as efficiently as possible (Skurnik 2002; Toms 2012). Otherwise, if a CE starts sliding into inefficiency, its members will lose the incentive to belong to a CE. A worker CE is an example of how ownership and governance structure play a role in balancing the tensions between economic and social aims to achieve success. A comparative case study of two large retailers in Europe, namely the Eroski group in Spain and the John Lewis Partnership in the UK, shows that it is possible be efficient and deliver excellent performance, even while facing economic and market challenges (Storey et al. 2014). Table 3 summarize various types of CE by ownership and business activity.

\section{Cooperative Enterprise Efficiency and Performance}

It is not possible to explain the present success of $\mathrm{CE}$ without analysing their advantages over their competitors. Therefore, market competitors have to be assessed (Fridell 2009). For that reason, scholars usually compare CE to corporations or IOFs, as to identify the differences between the economic behaviour of the different organizational forms, and thus to obtain a benchmark for measuring the $\mathrm{CE}$ against the IOF.

The debate about efficiency and performance in $\mathrm{CE}$ remains undecided. Although in the past the $\mathrm{CE}$ was considered less economically efficient than comparable IOFs, Bonin et al. (1993) presented evidence that theoretical and empirical studies about efficiency, productivity and survival of producer cooperatives are ambiguous. This argument was discussed by Sexton and Iskow (1993) from a theoretical standpoint, to show that $\mathrm{CE}$ could be as efficient as IOFs.

Nowadays, based on empirical studies into efficiency, there is no evidence to support the claim that IOFs are more 
Table 3 Typology of the cooperative enterprise by ownership and business activity

$\begin{aligned} & \text { Marketing or producer } \\ & \text { cooperative }\end{aligned}$
$\begin{aligned} & \text { A cooperative owned and democratically controlled by producers who band together to process or market their } \\ & \text { products } \\ & \text { A cooperative owned and democratically controlled by its worker-owners. Worker cooperatives enable members } \\ & \text { to obtain more favourable working conditions than those available on the market, both in terms of quality and } \\ & \text { economy } \\ & \text { A cooperative formed to purchase and supply goods and services on competitive conditions in the interest of } \\ & \text { members (retailers) } \\ & \text { Retail cooperative } \\ & \text { A cooperative owned and democratically controlled by its main consumers. Consumer cooperatives enable } \\ & \text { members to obtain supplies and/or durable goods on more favourable conditions than those available on the } \\ & \text { market } \\ & \text { A cooperative formed to aggregate demand to get lower prices from selected suppliers. It is often used to reduce } \\ & \text { procurement costs } \\ & \text { Cooperative bank, credit union, and insurance and other financial service cooperative. Private co-operative } \\ & \text { enterprise providing banking and financial intermediation services, democratically controlled by its member } \\ & \text { customers (borrowers and depositors). Consider credit unions and banks whose capital is composed by } \\ & \text { individuals without rights regarding the management of the bank. An insurance cooperative owned and } \\ & \text { democratically controlled by its main insured. Insurance cooperatives enable members to obtain insurance } \\ & \text { policies on more favourable conditions than those available on the market }\end{aligned}$
A cooperative formed to provide an owned or rented property on more favourable conditions than those available
on the market. This category includes both housing cooperative and cooperatives in the sector of Construction
A cooperative that manages health, social or educational services and productive activities for work integration of
Socially disadvantaged people
Social cooperative

NB: Many cooperatives are multi-functional; Table based on (Zeuli and Cropp 2004) and World Co-operative Monitor (WCM 2019)

efficient than CE. Market power and competition have pushed the $\mathrm{CE}$ to achieve greater technical efficiency (Maietta and Sena 2008). In fact, some empirical studies show that CE can obtain not only similar, but even higher efficiencies than IOFs (Terreros and Gorriz 2011), while they are always striving to become a cost-efficient player in their own business (Alavosius et al. 2009; Suzuki 2009). Further, studies that try to establish whether or not a CE size matters in affecting the performance and efficiency of the $\mathrm{CE}$, have ambiguous and often even contradictory results. In fact, studies do not show a clear relation between organizational size and performance (Campos-Climent and Sanchis-Palacio 2015). Soboh et al. (2009) present a theoretical and empirical review of the economic literature on performance in agricultural marketing cooperatives. Their review looked at theoretical approaches and empirical studies from economic and financial perspectives. The study shows three distinct views of the CE, as a vertical integration firm, an independent firm, and a coalition of firms. Despite theoretical and empirical studies recognizing the differences between IOFs and CE, empirical studies find the $\mathrm{CE}$ to be the same as an IOF. Further, the data used to analyse cooperative efficiency and performance is generally in the form of financial ratios (Othman et al. 2014).

Soboh et al. (2009) point out that for the CE, a pure financial focus does not provide due consideration of the member perspective of the CE being a firm with a dual purpose and multiple objectives. However, to assess the performance of the CE using the views of a vertical integration or a coalition of firms is difficult. Soboh et al. (2009) established that in order to perform a comparative study, it is necessary to collect information not only from the $\mathrm{CE}$ itself but additionally from both the members at the moment they join a $\mathrm{CE}$ and firms that decided not to join a CE. Finally, some studies tried to assess the social aspect of the $\mathrm{CE}$, and therefore focussed on the aspect of created social value, which is also an important position to consider. The CE's social component means that some consider it to be a not-for-profit organization (Costa et al. 2012).

\section{Cooperative Enterprise Strategy and Growth}

In a world dominated by corporations and IOFs, the strategy of the firm plays a key role in the road-map for companies to survive in the market (Porter 2008). Corporations and firms follow different strategies to be competitive and efficient (Porter and Kramer 2006; Teece 2010). Therefore, for CE sustainability in the long term, strategy management is important.

The CE has to face challenges such as globalization and trade liberalization in sectors such as agribusiness (Campos-Climent et al. 2012). Also, sometimes strategies have to be reshaped, even exploiting existing resources to 
deliver a complex service, such as assisting the elderly or the disabled (Canet-Giner et al. 2010). This is even more valid in highly competitive markets with intensive capital investments, such as the US Bio-ethanol industry that was investigated by Boone and Ozcan (2016). They discuss how the CE's strategic choice to enter this market explains their survival and endurance in comparison to IOFs.

Creating strategic alliances allows CE to achieve their goals (Fazzi 2012). Koljatic and Silva (2011) reported an exploratory study in which, despite operating as CE, certain undertakings involved in traditional sectors within traditional business such as collecting solid waste (paper, cardboard, glass and plastic) or arts and crafts, can achieve improved performance by arranging strategic alliances with both public and private partners. This they do by giving them access to resources and training, and particularly by helping them to sell their products. CE use other strategies such as mergers and acquisitions similarly (Worthington 2004). Further, CE have incorporated internationalization (Flecha and Ngai 2014; Molina 2012), vertical integration (Boland et al. 2007), diversification and R\&D as strategies in their growth models (Julia-Igual et al. 2012).

One example of strategy implementation in a CE is the case of an Italian retailing cooperative. Battaglia et al. (2015) investigated how a cooperative implemented sustainability accounting in response to a variety of market pressures and tensions. The results of this strategy reinforced the CE's level of mutuality and increased the social and economic value added.

Further, survival and growth of the CE also depend on how the $\mathrm{CE}$ is willing to handle its specific context. Referring to handling the context, we have not only internal factors in mind, but also external factors that affect the performance and growth of CE. For instance, Ekberg (2012) shows the case of Western European consumer CE, and how these $\mathrm{CE}$ responded to different revolutions in the food retailing market, i.e. to the supermarket revolution, the chain store revolution and the consumer revolution. In addition, effects of constrained supply and price contracts are also reported (Hovelaque et al. 2009). Also, Gagliardi (2009) published an empirical study about the relation between local banking institutions' development and that of cooperative firms which suggests that both the $\mathrm{CE}$ and the IOF tend to grow with local banks' support. However, the CE tended to grow less than the IOF; therefore, one key external factor of firm growth was shown to be local banking institutions' development.

\section{Cooperative Enterprise as Social Enterprise and Hybrid}

Over the past decade, there has been increasing scholarly attention to organizations that combine business and social purpose (Bacq and Janssen 2011; Doherty et al. 2014; Laville and Nyssens 2001). In various fields this type of organization is labelled as a social enterprise (SE) (Laville and Nyssens 2001; OECD 1999). What is key to remember for $\mathrm{CE}$ is that both the combination of business and social purpose is important, but also the entrepreneurial opportunities that $\mathrm{CE}$ will need to pursue. Additional key factors that characterize the $\mathrm{CE}$ are social and environmental sustainability (Hart and Milstein 2003), corporate social responsibility (Battaglia et al. 2015), and ethical and social responsibility.

SE are highly diverse, taking various legal forms in different countries (OECD 1999). As an organizational form, the SE is often described as a hybrid (Peredo and McLean 2006). The hybrids combine for-profit with nonprofit organizational features (Puusa et al. 2016), thereby pursuing a double bottom line (Bacq and Janssen 2011) with both economic and social goals (Battilana and Dorado 2010; Battilana et al. 2012). Therefore, organizations such as cooperatives, mutual benefit societies and associations were included in the SE category (Laville and Nyssens 2001). The boundaries of such SEs are rather fuzzy, and therefore not easy to determine (Mueller et al. 2015), even more so if it is a CE, The CE as an organizational form exists in continuous conflict between goals and values, as a hybrid (Ashforth and Reingen 2014). Moreover, the CE regularly exceeds boundaries within the institutional context, also overlapping with traditional categories of organizational forms such as private, public and non-profit organizations (Brandsen and Karré 2011). Hence, the complexity in which the $\mathrm{CE}$ is embedded makes it hard to categorize. Still, CE is considered as an SE and a hybrid that generates both economic and social benefits (Battilana and Lee 2014; Mazzarol et al. 2014b).

\section{Cooperatives and Social Entrepreneurship}

Specifically, insights for CEs can be drawn from the social entrepreneurship literature. Even with various schools of thought on social entrepreneurship (Bacq and Janssen 2011), the CE shares some characteristics with social entrepreneurship (Chell 2007). Both the social element and an entrepreneurial element are present (Lan et al. 2014; Mair and Marti 2006). The first common feature is setting their main mission as one linked to a social goal. Secondly, both business forms entail processes of identifying, evaluating and exploiting social opportunities (Bacq and Janssen 2011), and finally, they both create new social 
ventures (Zahra et al. 2008). Articulating this, Diaz-Foncea and Marcuello (2013, p. 245) propose a complete definition of cooperative entrepreneurship as "a group who manage the venture creation process, take risk and make judgmental decisions to create a business in a participatory way with the objective of obtaining mutual benefit to be distributed with equity among them".

A social entrepreneur's main goal is to create social value for overcoming social problems and market failures. This pre-condition is also present in the CE process. For instance, a study conducted in a rural cooperative development in China suggests that social entrepreneurship in rural cooperative development has multiple characteristics which include the institutional setting, contextual factors, historical path and personal experiences (Lan et al. 2014). However, although the social goals are important to $\mathrm{CE}$ and SE alike, we also need to underscore the wealth of opportunities created by following an entrepreneurial approach (Gawell 2013a). Entrepreneurs can choose the legal form and organizational model of their new ventures from several options of for-profit and non-profit organizations, of which one is the CE (Diaz-Foncea and Marcuello 2015). In this regard, the $C E$ offers people opportunities for creating new ventures-albeit that necessity driven entrepreneurship should not be ignored (Gawell 2013a). The case of women's cooperatives in India illustrates a significant contribution to wealth creation (Datta and Gailey 2012) and women's empowerment (Lecoutere 2017). Self-employment also offers opportunities that contribute to social inclusion. Additionally, scholars put forward other reasons that explain why the $\mathrm{CE}$ firm formation is an attractive option. For instance, in the case for cooperatives with the American Capitalist system anti-corporate movements (Schneiberg 2013), social movements (Schneiberg et al. 2008), collective actions (Baranchenko and Oglethorpe 2012) and institutional considerations provide such reasons (Boone and Ozcan 2013).

Reducing unemployment remains as one of the biggest challenges for governments worldwide. Various studies have shown the role that $\mathrm{CE}$ can play in reducing unemployment (Diaz-Foncea and Marcuello 2015; Kalmi 2013). In addition, Diaz-Foncea and Marcuello (2015) shows the patterns of firm formation in Spain. One of the findings of their study is that worker cooperatives are more disconnected from the economic dynamic than IOFs. That indicates the prevailing level of unemployment to be the main determinant in workers' cooperative formation. Further, the formation rate of cooperatives is higher in areas characterized by high unemployment.

Therefore, both society and public institutions recognize that firm formation as a part of the entrepreneurial process is a driving force for economic development. This is illustrated by a case in Papua New Guinea in which the government and public institutions revitalized $\mathrm{CE}$ by implementing a reformed cooperative policy for economic growth, and thus showing that the $\mathrm{CE}$ is a suitable vehicle for economic and social development (Garnevska et al. 2014). Hence, the role governments play in setting the institutional context to foster $\mathrm{CE}$ as essential tools in combatting poverty, helps in economic development and social entrepreneurship (Cox and Le 2014; Vuotto 2012).

Finally, the role that universities play in entrepreneurship, technological entrepreneurship and innovation systems is widely known (Van Looy 2009; Wells 2012), However, we do not yet know much about the contribution of supporting firm formation process in other types of organization such as CE. Here, the case of technological incubators of popular cooperatives in Brazil (Leca et al. 2014), this study provides a starting point for understanding the new paths for universities can take, with new roles to play in entrepreneurship, especially in worker cooperatives. This case shows how the University of Rio de Janeiro's initiative is a reaction to the country's growing unemployment.

\section{Comparison to Social Issues literature}

The 'social issues' field primarily focusses on the alleviation of human and social problems. However, over the past five years interest in SE, including the CE is booming in the social issues' literature, e.g. (Defourny et al. 2020) and is perceived as an effective means to alleviate human or social problems. Interestingly, in our systematic review, a disconnect seems to exist between the mainstream organizational literature in economics, business, management and sociology, and the social issues literature. Therefore, we provide a brief overview of the main themes discussed in three of the leading social issues journals with respect to $\mathrm{CE}$ and $\mathrm{SE}$ as a means to cross-fertilize organizational and social issues literature (Valentinov and Iliopoulos 2013).

We searched the Web of Science 'social issues' category for papers on cooperatives. The fast majority of papers was published in three journals: Voluntas (18), Nonprofit and Voluntary Sector Quarterly (11), and the Journal of Social Issues (2) - arguably the three leading social issues journals. After scanning abstracts in these three journals, 31 papers remained that dealt with cooperatives. Three key themes emerge from these 31 papers: national historical development, demarcation of the concept, and focus on social impact.

First of all, the literature mainly focusses on the (historical) development of cooperatives, often in a specific sector, in one country. Studied countries are Canada, Bolivia, Germany, Italy, Nicaragua, Portugal, Spain, Scotland, South Korea, Sweden, Ukraine and the USA. Sectors studied are for example (rental) housing, finance 
(credit unions, microfinance institutions, banking), agriculture, child day care, and education. Second, more recently, social issues scholars have attempted to develop typologies with respect to the broader concept of SE, including CE (Bidet et al. 2018; Defourny et al. 2020), with special attention to the hybrid balance between social and market identity, e.g. (Avila and Amorim 2020). In this way, social issues scholars aim to abstract from findings on SE in various countries and synthesize existing knowledge. Third, the explicit attention to emancipatory issues is striking in contrast with the organizational literature. For example, indigenous and colonial heritage (Ferguson 2018), solidarity economy (Bell, Leopold, Berry, and Hall 2018), immigrant employment (Sala-Rios et al. 2017), women participation (Bezboruah and Pillai 2015). Attention to specific organizational aspects is rather limited: starting a social venture (Edenfield and Andersson 2018), regeneration during crisis (Narvaiza et al. 2017), governance (Hatak et al. 2016), and strategizing (Jager and Beyes 2010). Considering the different foci, while having similar debates on hybridity, there seems to be much opportunity for cross-fertilization of both streams of knowledge.

\section{Conclusions and Avenues for Future Research}

The global financial crisis that started in 2007 revealed structural economic market problems. The serious difficulties private and public sectors experienced, boosted the research interest in alternative organizational forms that could provide innovative solutions to the market and society at large (Gawell 2013b). However, organizations with a not-for-profit and social orientation-such as volunteer organizations and associations-suffer from limited resources to support their daily activity as these organizational forms (partly) depend on donations, sponsorships, grants and/or philanthropy. Therefore, over the past decade management scholars have turned their attention to alternative organizational forms, such as $\mathrm{CE}$ and SE which try to address the global challenges and blend social and economic value (Battilana and Dorado 2010; Battilana and Lee 2014; Doherty et al. 2014), improving the living and working conditions of people globally.

The cooperative movement has a key role in social and economic development ever since the Rochdale Society in the nineteenth century (Wilson et al. 2012) which developed into the modern co-operative movement in the twentieth century (Wilson et al. 2013). Although, CE is not a new phenomenon, it is worthy to be rediscovered in the organizational literature. Some studies have demonstrated how the $\mathrm{CE}$ is often overseen, particularly in textbooks (Hill 2000; Kalmi 2007). Therefore, we investigated and disclosed a range of possible reasons for such limited attention to the CE. This paper also discussed some of the underlying reasons for limited attention and how these reasons need to be reappraised at present.

We conducted the systematic literature review to identify the current knowledge and research about $\mathrm{CE}$ in the mainstream organizational literature: drawn from the economics, business, management and sociology fields. This review allowed us to categorize relevant studies and provide an overview of main themes according to our conceptbased approach. Further, this study provides a range of concepts and topics that scholars have studied. Our comparison between the CE and IOF as competitors within the economic market is a way of assessing them and establishing a benchmark (Fridell 2009). However, it is always an incomplete assessment, due also to scholars generally missing the social component of the $\mathrm{CE}$, and focusing their efforts on financial and productivity ratios (Costa et al. 2012; Soboh et al. 2009). Nonetheless, the CE faces other tensions, conflicts and dualities as well (Ashforth and Reingen 2014), the CE has shown remarkable stability and resilience in dealing with crises (Birchall 2013), therefore we propose that the $\mathrm{CE}$ as an organizational form should both be seen as an appropriate organizational form for a wide range of contexts and a type of Social Enterprise that can very well combine social and economic value. Various reasons for the limited attention to $\mathrm{CE}$ were debunked, including its inefficiency, while the many options for ownership and governance structures where presented. Still, there are many opportunities for future research on $\mathrm{CE}$, of which the main avenues are discussed below.

First of all, studies that involve research in different or single levels of analysis are widely known in organizational literature, looking at, e.g. individuals, groupslteams, organizations, industry, country or geographic region. Nevertheless, the majority of the scholarly work listed in our review belong to a macro level of analysis such as organization, country and industry. However, studies that analyse CE in other levels of analysis such as that of the individual, team or group, and at the inter-organizational level of analysis, remain scarce. Hence, research that will develop a better understanding of $\mathrm{CE}$ using multilevel analysis, is a still worthy endeavour (Hitt et al. 2007).

Second, studies that examine how the social component of the CE can be assessed are scarce. That in itself is a challenge, and more so if researchers want insight into both social and economic components in order to obtain a full picture of CE's nature. As we mentioned, CE have a broad social mission beyond their economic role (Kalmi 2007). All types of CE attend to improving capabilities of its members, promoting social stability and trust, building up social capital among members, community and stakeholders (Hatak et al. 2016). Additionally, there is evidence 
that CE perform better than IOF when for example organizational misconduct is considered (Ehrenhard and Fiorito 2018). Thereby, some research questions related to the process of sounding out the complete nature of a CE arise, asking, e.g. how $\mathrm{CE}$ engage in both communities and society for local development, what governance mechanisms are used to balance the social as well as economic impact, in which context is the economic performance of $\mathrm{CE}$ comparable or superior to IOF, and what role is the CE form playing in contemporary societies across the globe?

Third, in recent years new challenges have emerged for sustainable development and $\mathrm{CE}$ as well. Such challenges relate to issues such as climate change, the use and exploitation of natural resources, the digital work force, (gender) inequality, sustainable development, and grand societal challenges (George et al. 2016). Some of these issues have received much more attention in the social issues' literature. Research questions deserving of scholarly attention in this area refer to how these challenges affect $\mathrm{CE}$ and how $\mathrm{CE}$ can or should respond to them. Such challenges bring new avenues to be studied in the quest for fitting organizational structures, corporate governance regimes, and necessary organizational changes. As a consequence, the question rises what types of strategies $\mathrm{CE}$ need to follow in addressing these challenges. Thus, knowledge of CE's management practices can be much improved.

Fourth, nowadays a key factor in giving firms a competitive advantage is entrepreneurial opportunity generation especially in relation to innovation (Gawell 2013b). Recent research has shown that innovation does not happen in isolation, but that it occurs within a collaborative context. However, studies that link innovation to $\mathrm{CE}$ in intra and inter-organizational context have not yet received much attention. Research questions to be answered in this regard, include considering how the journey of new product development is structured in a $\mathrm{CE}$, whether or not $\mathrm{CE}$ are involved in $R \& D$ activities, how $C E$ reacts to developing or implementing new technologies, what type of technologies enhance CE performance, and more recently trends such as artificial intelligence and smart industry. In addition, it is well-known that cooperation and collaboration between companies as partners (Barringer and Harrison 2000; Strand and Freeman 2015) and in alliances (Fornell et al. 1990), hold advantages for companies that work in an inter-organizational relationship, improving performance and developing competitive advantage (Fazzi 2012). Also, the early process of cooperative formation is not much studied and would benefit from the work on community self-organizing, e.g. the study by Edelenbos et al. (2018). One way to achieve competitive advantage is through vertical integration, scaling up their efforts and managing resources efficiently through a CE (Hendrikse and Feng 2013), besides gain access to resources, information and inputs (Morfi et al. 2018). Therefore, considering that from the members' perspective a CE has a dependent nature, encourages us to explore the research questions about how $\mathrm{CE}$ and members work together as a network. Likewise, based on the 6th principle of cooperatives "Co-operation among Cooperatives" (ICA 2020b), we should also consider the network between cooperatives, (Menzani and Zamagni 2010).

\section{Limitations}

We recognize that our study has various limitations. Firstly, we were challenged with having to find a good search string, since the word cooperative, or co-operative, is widely used as a concept with various meanings in different fields, but at the same time is used to identify CE as an organizational form. Secondly, we could not provide an exhaustive account of everything written about CE, because there is extensive literature on such entities in other related fields and our focus was mainly to synthesize the knowledge in the mainstream organizational literature and provide future research avenues. We examined the literature to obtain a state-of-the-art account of the CE in the organizational literature. Thirdly, although the review protocol uses a recognized database such as the Web of Science, despite our back- and forward search, we could have omitted other relevant research published before our protocol time-line, as well as research recorded in other databases. Finally, we provide evidence, maintain objectivity and independence regarding the current body of knowledge (Pawson 2013).

Open Access This article is licensed under a Creative Commons Attribution 4.0 International License, which permits use, sharing, adaptation, distribution and reproduction in any medium or format, as long as you give appropriate credit to the original author(s) and the source, provide a link to the Creative Commons licence, and indicate if changes were made. The images or other third party material in this article are included in the article's Creative Commons licence, unless indicated otherwise in a credit line to the material. If material is not included in the article's Creative Commons licence and your intended use is not permitted by statutory regulation or exceeds the permitted use, you will need to obtain permission directly from the copyright holder. To view a copy of this licence, visit http://creativecommons. org/licenses/by/4.0/.

\section{References}

Ackermann, J. (2008). The subprime crisis and its consequences. Journal of Financial Stability, 4, 329-337.

Alavosius, M., Getting, J., Dagen, J., Newsome, W., \& Hopkins, B. (2009). Use of a cooperative to interlock contingencies and balance the commonwealth. Journal of Organizational Behavior Management, 29, 193-211. 
Albers, S., Wohlgezogen, F., \& Zajac, E. J. (2016). Strategic alliance structures: An organization design perspective. Journal of Management, 42(3), 582-614. https://doi.org/10.1177/ 0149206313488209.

Ashforth, B. E., \& Reingen, P. H. (2014). Functions of dysfunction: Managing the dynamics of an organizational duality in a natural food cooperative. Administrative Science Quarterly, 59, 474-516.

Avila, L., \& Amorim, M. (2020). Organisational identity of social enterprises: A taxonomic approach. VOLUNTAS: International Journal of Voluntary and Nonprofit Organizations. https://doi. org/10.1007/s11266-020-00264-z.

Bacq, S., \& Janssen, F. (2011). The multiple faces of social entrepreneurship: A review of definitional issues based on geographical and thematic criteria. Entrepreneurship and Regional Development, 23, 373-403.

Balnave, N., \& Patmore, G. (2010). Marketing community and democracy: Rural Rochdale co-operatives in Australia. Consumption Markets \& Culture, 13, 61-77.

Balnave, N., \& Patmore, G. (2012). Rochdale consumer co-operatives in Australia: Decline and survival. Business History, 54, 986-1003.

Baranchenko, Y., \& Oglethorpe, D. (2012). The potential environmental benefits of co-operative businesses within the climate change agenda. Business Strategy and the Environment, 21, 197-210.

Barringer, B. R., \& Harrison, J. S. (2000). Walking a tightrope: Creating value through interorganizational relationships. Journal of Management, 26, 367-403.

Battaglia, M., Bianchi, L., Frey, M., \& Passetti, E. (2015). Sustainability reporting and corporate identity: Action research evidence in an Italian retailing cooperative. Business Ethics: A European Review, 24, 52-72.

Battilana, J., \& Dorado, S. (2010). Building sustainable hybrid organizations: The case of commercial microfinance organizations. Academy of Management Journal, 53, 1419-1440.

Battilana, J., \& Lee, M. (2014). Advancing research on hybrid organizing-Insights from the study of social enterprises. Academy of Management Annals, 8, 397-441.

Battilana, J., Lee, M., Walker, J., \& Dorsey, C. (2012). In search of the hybrid ideal. Stanford Social Innovation Review, 10, 50-55.

Battilani, P., \& Zamagni, V. (2012). The managerial transformation of Italian co-operative enterprises 1946-2010. Business History, 54, 964-985.

Bell, M. P., Leopold, J., Berry, D., \& Hall, A. V. (2018). Diversity, discrimination, and persistent inequality: Hope for the future through the solidarity economy movement. Journal of Social Issues, 74(2), 224-243. https://doi.org/10.1111/josi.12266.

Bernardi, A., \& Greenwood, A. (2014). Old and new rural cooperative medical scheme in China: the usefulness of a historical comparative perspective. Asia Pacific Business Review, 20, 356-378.

Bernardi, A., \& Miani, M. (2014). The long march of Chinese cooperatives: Towards market economy, participation and sustainable development. Asia Pacific Business Review, 20, 330-355.

Bezboruah, K. C., \& Pillai, V. (2015). Exploring the participation of women in financial cooperatives and credit unions in developing countries. VOLUNTAS: International Journal of Voluntary and Nonprofit Organizations, 26(3), 913-940. https://doi.org/10. 1007/s11266-014-9467-9.

Bidet, E., Eum, H., \& Ryu, J. (2018). Diversity of social enterprise models in South Korea. VOLUNTAS: International Journal of Voluntary and Nonprofit Organizations, 29(6), 1261-1273. https://doi.org/10.1007/s11266-018-9951-8.

Birchall, J. (2010). People-centred businesses: Co-operatives, mutuals and the idea of membership. London: Palgrave Macmillan.
Birchall, J. (2013). The potential of co-operatives during the current recession; theorizing comparative advantage. Journal of Entrepreneurial and Organizational Diversity, 2, 1-22.

Boland, M. A., Bosse, A., \& Brester, G. W. (2007). The mountain states lamb cooperative: Can vertical integration keep lamb producers from being fleeced? Review of Agricultural Economics, 29, 157-169.

Bonin, J. P., Jones, D. C., \& Putterman, L. (1993). Theoretical and empirical-studies of producer cooperatives-Will ever the twain meet. Journal of Economic Literature, 31, 1290-1320.

Boone, C., \& Ozcan, S. (2013). Why do cooperatives emerge in a world dominated by corporations? The diffusion of cooperatives in the U.S. Bio-Ethanol Industry, 1978-2013. Academy of Management Journal, 57, 990-1012.

Boone, C., \& Ozcan, S. (2016). Strategic choices at entry and relative survival advantage of cooperatives versus corporations in the US Bio-Ethanol Industry, 1978-2015. Journal of Management Studies, 53, 1113-1140.

Brandsen, T., \& Karré, P. M. (2011). Hybrid organizations: No cause for concern? International Journal of Public Administration, 34, $827-836$

Campos-Climent, V., Apetrei, A., \& Chaves-Avila, R. (2012). Delphi method applied to horticultural cooperatives. Management Decision, 50, 1266-1284.

Campos-Climent, V., \& Sanchis-Palacio, J. R. (2015). How much does size matter in agri-food firms? Journal of Business Research, 68, 1589-1591.

Canet-Giner, M. T., Fernandez-Guerrero, R., \& Peris-Ortiz, M. (2010). Changing the strategy formation process in a service cooperative. Journal of Organizational Change Management, $23,435-452$.

Chaddad, F. R., \& Cook, M. L. (2004). Understanding new cooperative models: An ownership-control rights typology. Review of Agricultural Economics, 26, 348-360.

Chell, E. (2007). Social enterprise and entrepreneurship-Towards a convergent theory of the entrepreneurial process. International Small Business Journal, 25, 5-26.

Cheney, G., Cruz, I. S., Peredo, A. M., \& Nazareno, E. (2014). Worker cooperatives as an organizational alternative: Challenges, achievements and promise in business governance and ownership. Organization, 21, 591-603.

Costa, E., Andreaus, M., Carini, C., \& Carpita, M. (2012). Exploring the efficiency of Italian social cooperatives by descriptive and principal component analysis. Service Business, 6, 117-136.

Cox, A., \& Le, V. (2014). Governmental influences on the evolution of agricultural cooperatives in Vietnam: an institutional perspective with case studies. Asia Pacific Business Review, 20, 401-418.

Datta, P. B., \& Gailey, R. (2012). Empowering women through social entrepreneurship: Case study of a women's cooperative in India. Entrepreneurship Theory and Practice, 36, 569-587.

Defourny, J., \& Nyssens, M. (2017). Mapping social enterprise models: some evidence from the "ICSEM" project. Social Enterprise Journal, 13(4), 318-328. https://doi.org/10.1108/sej09-2017-0049.

Defourny, J., Nyssens, M., \& Brolis, O. (2020). Testing social enterprise models across the world: Evidence from the "International Comparative Social Enterprise Models (ICSEM) Project." Nonprofit and Voluntary Sector Quarterly. https://doi.org/ 10.1177/0899764020959470.

Diaz-Foncea, M., \& Marcuello, C. (2013). Entrepreneurs and the context of cooperative organizations: A definition of cooperative entrepreneur. Canadian Journal of Administrative SciencesRevue Canadienne Des Sciences De L Administration, 30, 238-251. 
Diaz-Foncea, M., \& Marcuello, C. (2015). Spatial patterns in new firm formation: Are cooperatives different? Small Business Economics, 44, 171-187.

Doherty, B., Haugh, H., \& Lyon, F. (2014). Social enterprises as hybrid organizations: A review and research agenda. International Journal of Management Reviews, 16, 417-436.

Edelenbos, J., van Meerkerk, I., \& Schenk, T. (2018). The evolution of community self-organization in interaction with government institutions: Cross-case insights from three countries. The American Review of Public Administration, 48(1), 52-66.

Edenfield, A. C., \& Andersson, F. O. (2018). Growing pains: The transformative journey from a nascent to a formal not-for-profit venture. VOLUNTAS: International Journal of Voluntary and Nonprofit Organizations, 29(5), 1033-1043. https://doi.org/10. 1007/s11266-017-9936-z.

Ehrenhard, M. L., \& Fiorito, T. L. (2018). Corporate values of the 25 largest European banks: Exploring the ambiguous link with corporate scandals. Journal of Public Affairs, 18(1), e1700.

Ekberg, E. (2012). Confronting three revolutions: Western European consumer co-operatives and their divergent development, 1950-2008. Business History, 54, 1004-1021.

EPA, U. S. E. P. A. (2016). United States Files Complaint Against Volkswagen, Audi and Porsche for Alleged Clean Air Act Violations. Retrieved from https://www.epa.gov/newsreleases/ united-states-files-complaint-against-volkswagen-audi-andporsche-alleged-clean-air-act

Fahlbeck, E. (2007). The horizon problem in agricultural cooperatives only in theory? In K. Karantininis \& J. Nilsson (Eds.), Vertical markets and cooperative hierarchies (pp. 255-274). Dordrecht: Springer.

Fazzi, L. (2012). Social enterprises, models of governance and the production of welfare services. Public Management Review, 14(3), 359-376.

Ferguson, G. (2018). The social economy in Bolivia: Indigeneity, solidarity, and alternatives to capitalism. VOLUNTAS: International Journal of Voluntary and Nonprofit Organizations, 29(6), 1233-1243. https://doi.org/10.1007/s11266-018-0013-z.

Fernandez, E. (2014). Selling agricultural products: Farmers' cooperatives in production and marketing, 1880-1930. Business History, 56, 547-568.

Flecha, R., \& Ngai, P. (2014). The challenge for Mondragon: Searching for the cooperative values in times of internationalization. Organization, 21, 666-682.

Fornell, C., Lorange, P., \& Roos, J. (1990). The cooperative venture formation process-A latent variable structural modeling approach. Management Science, 36(10), 1246-1255. https:// doi.org/10.1287/mnsc.36.10.1246.

Fridell, G. (2009). The co-operative and the corporation: Competing visions of the future of fair trade. Journal of Business Ethics, 86, 81-95.

Gagliardi, F. (2009). Financial development and the growth of cooperative firms. Small Business Economics, 32, 439-464.

Garnevska, E., Joseph, H., \& Kingi, T. (2014). Development and challenges of cocoa cooperatives in Papua New Guinea: Case of Manus province. Asia Pacific Business Review, 20, 419-438.

Gawell, M. (2013a). Social entrepreneurship: Action grounded in needs, opportunities and/or perceived necessities? VOLUNTAS: International Journal of Voluntary and Nonprofit Organizations, 24(4), 1071-1090. https://doi.org/10.1007/s11266-012-9301-1.

Gawell, M. (2013b). Social entrepreneurship-Innovative challengers or adjustable followers? Social Enterprise Journal, 9(2), 203-220. https://doi.org/10.1108/SEJ-01-2013-0004.

George, G., Howard-Grenville, J., Joshi, A., \& Tihanyi, L. (2016). Understanding and tackling societal grand challenges through management research. Academy of Management Journal, 59, $1880-1895$.
Hansmann, H. (1996). The ownership of enterprise. Cambridge: Harvard University Press.

Hansmann, H. (1999). Cooperative firms in theory and practice. Liiketaloudellinen aikakauskirja, 387-403.

Hart, S. L., \& Milstein, M. B. (2003). Creating sustainable value. Academy of Management Executive, 17, 56-67.

Harvey, D. (2005). A brief history of neoliberalism. Oxford: Oxford University Press.

Hatak, I., Lang, R., \& Roessl, D. (2016). Trust, social capital, and the coordination of relationships between the members of cooperatives: A comparison between member-focused cooperatives and third-party-focused cooperatives. VOLUNTAS: International Journal of Voluntary and Nonprofit Organizations, 27, 1218-1241.

Hendrikse, G. W. J., \& Feng, L. (2013). Interfirm cooperatives. In A. Grandori (Ed.), Handbook of economic organization: Integrating economic and organization theory (pp. 501-521). Cheltenham: Edward Elgard.

Hendrikse, G. W. J., \& Veerman, C. P. (2001). Marketing cooperatives and financial structure: a transaction costs economics analysis. Agricultural Economics, 26, 205-216.

Hill, R. (2000). The case of the missing organizations: Co-operatives and the textbooks. Journal of Economic Education, 31, 281-295.

Hitt, M. A., Beamish, P. W., Jackson, S. E., \& Mathieu, J. E. (2007). Building theoretical and empirical bridges across levels: Multilevel research in management. The Academy of Management Journal, 50, 1385-1399.

Hovelaque, V., Duvaleix-Treguer, S., \& Cordier, J. (2009). Effects of constrained supply and price contracts on agricultural cooperatives. European Journal of Operational Research, 199, 769-780.

ICA. (2020a). Cooperative identity. Retrieved from https://www.ica. coop/en/cooperatives/cooperative-identity

ICA. (2020b). What is a cooperative. Retrieved from https://www.ica. coop/en/cooperatives/what-is-a-cooperative

ILO. (2002). International Labour Organization. Promotion of cooperatives recommendation (No. 193). Retrieved from http:// www.ilo.org/dyn/normlex/en/f?p=NORMLEXPUB:12100:0: NO::P12100_ILO_CODE:R193

ILO. (2017). Cooperatives. Retrieved from http://libguides.ilo.org/ cooperatives-en

Jager, U., \& Beyes, T. (2010). Strategizing in NPOs: A case study on the practice of organizational change between social mission and economic rationale. VOLUNTAS: International Journal of Voluntary and Nonprofit Organizations, 21(1), 82-100. https:// doi.org/10.1007/s11266-009-9108-x.

Jaumier, S. (2017). Preventing chiefs from being chiefs: An ethnography of a co-operative sheet-metal factory. Organization, 24, 218-239.

Julia-Igual, J. F., Melia-Marti, E., \& Garcia-Martinez, G. (2012). Strategies developed by leading EU agrifood cooperatives in their growth models. Service Business, 6, 27-46.

Kalmi, P. (2007). The disappearance of cooperatives from economics textbooks. Cambridge Journal of Economics, 31, 625-647.

Kalmi, P. (2013). Catching a wave: The formation of co-operatives in Finnish regions. Small Business Economics, 41, 295-313.

Katz, J. P., \& Boland, M. A. (2002). One for all and all for one? A new generation of co-operatives emerges. LONG RANGE PLANNING, 35, 73-89.

Koljatic, M., \& Silva, M. (2011). Alliances in SMEs and cooperatives involved in business with low income sectors in Latin America. Innovar-Revista De Ciencias Administrativas Y Sociales, 21, $127-135$.

Kotler, P., \& Lee, N. (2005). Corporate social responsability: Doing the most good for your company and your cause. NJ: Wiley.

Lambru, M., \& Petrescu, C. (2014). Surviving the crisis: Worker cooperatives in Romania. Organization, 21, 730-745. 
Lan, H., Zhu, Y., Ness, D., Xing, K., \& Schneider, K. (2014). The role and characteristics of social entrepreneurs in contemporary rural cooperative development in China: Case studies of rural social entrepreneurship. Asia Pacific Business Review, 20, 379-400.

Laville, J. L., \& Nyssens, M. (2001). The social enterprise towards a theoretical socio-economic approach. In C. Borzaga \& J. Defourny (Eds.), The emergence of social enterprise (pp. 312-332). London: Routledge.

Leca, B., Gond, J. P., \& Cruz, L. B. (2014). Building "Critical Performativity Engines" for deprived communities: The construction of popular cooperative incubators in Brazil. Organization, 21, 683-712.

Lecoutere, E. (2017). The impact of agricultural co-operatives on women's empowerment: Evidence from Uganda. Journal of CoOperative Organization and Management, 5, 14-27.

Levi, Y., \& Davis, P. (2008). Cooperatives as the "enfants terribles" of economics: Some implications for the social economy. The Journal of Socio-Economics, 37, 2178-2188.

Limnios, E. M., Mazzarol, T., Soutar, G. N., \& Siddique, K. H. (2018). The member wears four hats: A member identification framework for cooperative enterprises. Journal of Co-Operative Organization and Management, 6, 20-33.

Loconto, A. M., \& Simbua, E. F. (2012). Making room for smallholder cooperatives in Tanzanian Tea Production: Can Fairtrade do that? Journal of Business Ethics, 108, 451-465.

Maietta, O. W., \& Sena, V. (2008). Is competition really bad news for cooperatives? Some empirical evidence for Italian producers' cooperatives. Journal of Productivity Analysis, 29, 221-233.

Mair, J., \& Marti, I. (2006). Social entrepreneurship research: A source of explanation, prediction, and delight. Journal of World Business, 41, 36-44.

Mangan, A., \& Byrne, A. (2018). Marginalising co-operation? A discursive analysis of media reporting on the Co-operative Bank. Organization, 25, 794-811.

Mason, D. L. (2012). The rise and fall of the cooperative spirit: The evolution of organisational structures in American thrifts, 1831-1939. Business History, 54, 381-398.

Mazzarol, T., Clark, D., Reboud, S., \& Limnios, E. M. (2018). Developing a conceptual framework for the co-operative and mutual enterprise business model. Journal of Management \& Organization, 24, 551-581.

Mazzarol, T., Limnios, E. M., \& Reboud, S. (2014a). An overview of the research. In T. Mazzarol, S. Reboud, E. M. Limnios, \& D. Clark (Eds.), Research handbook on sustainable co-operative enterprise case studies of organizational resilience in the cooperative business model (pp. 3-21). Cheltenham: Edward Elgar.

Mazzarol, T., Simmons, R., \& Limnios, E. M. (2014b). A conceptual framework for research into co-operative enterprises. In $\mathrm{T}$. Mazzarol, S. Reboud, E. M. Limnios, \& D. Clark (Eds.), Research Handbook on sustainable co-operative enterprise case studies of organizational resilience in the co-operative business model (pp. 22-50). Cheltenham: Edward Elgar.

Menzani, T., \& Zamagni, V. (2010). Cooperative networks in the Italian economy. Enterprise \& Society, 11, 98-127.

Mintzberg, H. (1996). Managing government-Governing management. Harvard Business Review, 74, 75-83.

Molina, F. (2012). Fagor Electrodomesticos: The multinationalisation of a Basque co-operative, 1955-2010. Business History, 54, 945-963.

Monteiro, N. P., \& Stewart, G. (2015). Scale, scope and survival: A Comparison of cooperative and capitalist modes of production. Review of Industrial Organization, 47, 91-118.

Morfi, C., Nilsson, J., \& Osterberg, H. (2018). Why farmers involve themselves in co-operative district councils. Annals of Public and Cooperative Economics, 89, 581-598.
Mueller, S., D’Intino, R. S., Walske, J., Ehrenhard, M. L., Newbert, S. L., Robinson, J. A., \& Senjem, J. C. (2015). What's holding back social entrepreneurship? Removing the impediments to theoretical advancement. Journal of Social Entrepreneurship, 6(3), 245-256.

Narvaiza, L., Aragon-Amonarriz, C., Iturrioz-Landart, C., BayleCordier, J., \& Stervinou, S. (2017). Cooperative dynamics during the financial crisis: Evidence from Basque and Breton case studies. Nonprofit and Voluntary Sector Quarterly, 46(3), 505-524. https://doi.org/10.1177/0899764016661775.

Novkovic, S. (2008). Defining the co-operative difference. The Journal of Socio-Economics, 37, 2168-2177.

Nunez-Nickel, M., \& Moyano-Fuentes, J. (2004). Ownership structure of cooperatives as an environmental buffer. Journal of Management Studies, 41, 1131-1152.

OECD. (1999). Social enterprises. Retrieved from https://www.oecdilibrary.org/urban-rural-and-regional-development/social-enter prises_9789264182332-en

Othman, A., Mansor, N., \& Kari, F. (2014). Assessing the performance of co-operatives in Malaysia: an analysis of cooperative groups using a data envelopment analysis approach. Asia Pacific Business Review, 20, 484-505.

Paranque, B., \& Willmott, H. (2014). Cooperatives-saviours or gravediggers of capitalism? Critical performativity and the John Lewis Partnership. Organization, 21, 604-625.

Parmigiani, A., \& Rivera-Santos, M. (2011). Clearing a path through the forest: a meta-review of interorganizational relationships. Journal of Management, 37, 1108-1136.

Pawson, R. (2013). The science of evaluation: a realist manifesto. UK: Sage.

Peredo, A. M., \& McLean, M. (2006). Social entrepreneurship: A critical review of the concept. Journal of World Business, 41, $56-65$.

Porter, M. E. (2008). The five competitive forces that shape strategy. Harvard Business Review, 86(1), 78-79.

Porter, M. E., \& Kramer, M. R. (2006). Strategy and society. Harvard Business Review, 84, 78-92.

Porter, P. K., \& Scully, G. W. (1987). Economic-efficiency in cooperatives. Journal of Law \& Economics, 30, 489-512.

Porter, \& Kramer. (2011). Creating shared value. Harvard Business Review, 89, 62-77

Putterman, L. G., \& Kroszner, R. (1996). The economic nature of the firm: a reader. Cambridge: Cambridge University Press.

Puusa, A., Hokkila, K., \& Varis, A. (2016). Individuality vs. communality-A new dual role of co-operatives? Journal of Co-Operative Organization and Management, 4, 22-30.

Robertson, N. (2012). Collective strength and mutual aid: Financial provisions for members of co-operative societies in Britain. Business History, 54, 925-944.

Sala-Rios, M., Farre-Perdiguer, M., \& Torres-Sole, T. (2017). Immigrants' employment in Spanish cooperatives: Outcomes in relation to the business cycle. VOLUNTAS: International Journal of Voluntary and Nonprofit Organizations, 28(5), 1940-1961. https://doi.org/10.1007/s11266-016-9817-x.

Sandmo, A. (2011). Economics evolving: a history of economic thought. Princeton: Princeton University Press.

Schneiberg, M. (2013). Movements as political conditions for diffusion: Anti-corporate movements and the spread of cooperative forms in American capitalism. Organization Studies, 34, 653-682.

Schneiberg, M., King, M., \& Smith, T. (2008). Social movements and organizational form: Cooperative alternatives to corporations in the American insurance, dairy, and grain industries. American Sociological Review, 73, 635-667. 
Sexton, R. J., \& Iskow, J. (1993). What do we know about the economic efficiency of cooperatives: an evaluative survey. Journal of Agricultural Cooperation, 8, 15-27.

Simmons, R., \& Birchall, J. (2008). The role of co-operatives in poverty reduction: Network perspectives. The Journal of SocioEconomics, 37, 2131-2140.

Skurnik, S. (2002). The role of cooperative entrepreneurship and firms in organising economic activities-Past, present and future. LTA, 103-124.

Soboh, R., Lansink, A. O., Giesen, G., \& van Dijk, G. (2009). Performance measurement of the agricultural marketing cooperatives: The gap between theory and practice. Review of Agricultural Economics, 31, 446-469.

Stiglitz, D. J. (2009). Moving beyond market fundamentalism to a balanced economy. Annals of Public and Cooperative Economics, 80, 345-360.

Storey, J., Basterretxea, I., \& Salaman, G. (2014). Managing and resisting "degeneration" in employee-owned businesses: A comparative study of two large retailers in Spain and the United Kingdom. Organization, 21, 626-644.

Strand, R., \& Freeman, R. E. (2015). Scandinavian cooperative advantage: The theory and practice of stakeholder engagement in Scandinavia. Journal of Business Ethics, 127, 65-85.

Suzuki, Y. (2009). Finding the proper fleet-downsizing strategies for U.S. agricultural cooperatives: A case of GROWMARK, Inc. Transportation Journal, 48, 24-39.

Teece, D. J. (2010). Business models, business strategy and innovation. LONG RANGE PLANNING, 43, 172-194.

Terreros, I. S., \& Gorriz, C. G. (2011). The effect of organizational form and vertical integration on efficiency: An empirical comparison between cooperatives and investor owned firms. African Journal of Business Management, 5, 168-178.

Toms, S. (2012). Producer co-operatives and economic efficiency: Evidence from the nineteenth-century cotton textile industry. Business History, 54, 855-882.

Tranfield, D., Denyer, D., \& Smart, P. (2003). Towards a methodology for developing evidence-informed management knowledge by means of systematic review. British Journal of Management, 14, 207-222.
Valentinov, V., \& Iliopoulos, C. (2013). Economic theories of nonprofits and agricultural cooperatives compared new perspectives for nonprofit scholars. Nonprofit and Voluntary Sector Quarterly, 42(1), 109-126.

Van Looy, B. (2009). The role of entrepreneurial universities within innovation systems: An overview and assessment. Review of Business and Economics, 54, 62-81.

Vuotto, M. (2012). Organizational dynamics of worker cooperatives in Argentina. Service Business, 6, 85-97.

WCM. (2019). World co-operative monitor. Retrieved from https:// monitor.coop/sites/default/files/publication-files/wcm2019-final1671449250.pdf

Webster, A. (2012). Building the wholesale: The development of the English CWS and British co-operative business 1863-90. Business History, 54, 883-904.

Wells, J. (2012). The role of universities in technology entrepreneurship. Technology Innovation Management Review, 2, 35-40.

Wilson, M., Shaw, L., \& Lonergan, G. (2012). Our story: Rochdale pioneers museum. In: UK: Rochdale: Co-operative Heritage Trust. www.rochdalepioneersmuseum.coop.

Wilson, J., Webster, A., \& Vorberg-Rugh, R. (2013). The Cooperative movement in Britain: From crisis to "renaissance", 1950-2010. Enterprise \& Society, 14(2), 271-302. https://doi. org/10.1093/es/khs076.

Worthington, A. C. (2004). Determinants of merger and acquisition activity in Australian cooperative deposit-taking institutions. Journal of Business Research, 57, 47-57.

Zahra, S. A., Rawhouser, H. N., Bhawe, N., Neubaum, D. O., \& Hayton, J. C. (2008). Globalization of social entrepreneurship opportunities. Strategic Entrepreneurship Journal, 2, 117-131.

Zeuli, K. A., \& Cropp, R. (2004). Cooperatives: Principles and practices in the 21 st century. In University, of, Wisconsin, Center, for, \& Cooperatives (Eds.). Retrieved from https:// staging.community-wealth.org/sites/clone.community-wealth. org/files/downloads/report-zeuli.pdf

Publisher's Note Springer Nature remains neutral with regard to jurisdictional claims in published maps and institutional affiliations. 